\title{
The Practice of the Psychologist in Brazilian Social Welfare
}

Allana Ribeiro Porto Sales ${ }^{*}, 1$

Orcid.org/0000-0003-4805-0384

Regina Heloisa Maciel ${ }^{1}$

Orcid.org/0000-0003-2933-7021

${ }^{1}$ Universidade de Fortaleza, Fortaleza, Ceará, Brasil

\begin{abstract}
The presence of psychologists in Brazilian social welfare has been increasing and the reality of psychology in this context is still surrounded by doubts and questions about the roles and identity of this professional in a social context of poverty and material needs. This article analyzes the psychologists' work in the social welfare context considering the working conditions of these professionals. Participants of the study were 1,100 psychologists of all Brazilian regions, who answered an online questionnaire covering sociodemographic and work issues. The main results indicate that social welfare psychologists are poorly remunerated, have extensive workloads and are not technically prepared to deal with the issues that arise in the institutions they work. It was also found that the technical references are vague and only highlight ways, not prescribing specific activities. Therefore, the professionals must use their own resources to achieve the National Social Assistance Policy goals, adopting a creative and inventive approach.
\end{abstract}

Keywords: Social and Work Psychology, work conditions, Social Welfare Policy, Unified Social Welfare System.

\section{A Atuação do Psicólogo na Assistência Social Brasileira}

\section{Resumo}

A presença de psicólogos na assistência social brasileira tem sido cada vez maior, porém a realidade da psicologia nesse contexto ainda é cercada por imprecisões e incertezas acerca dos papeis e da identidade desse profissional em um contexto social de pobreza e necessidades materiais. O presente artigo analisa o trabalho do psicólogo no âmbito da assistência social considerando as condições de trabalho desses profissionais. A pesquisa contou com a participação de 1100 psicólogos de todas as regiões do Brasil que responderam a um questionário online abrangendo questões sociodemográficas e laborais. Os resultados mostram que os psicólogos são mal remunerados, possuem carga horária extensa e não estão preparados

* Mailing address for the Editorial Board: Rua Duarte Pacheco, 1400, Cs 156, Bairro: Higienópolis, São José do Rio Preto, SP - Brazil 15085-140. Phones: (17) 3227-8495 / (17) 99671-4747. E-mail: allanaporto@gmail.com The study received partial funding from Coordenação de Aperfeiçoamento de Pessoal de Nível Superior (CAPES).

The present work is based on the doctoral thesis of the first author under the guidance of the second. 
tecnicamente para lidar com as questões que se apresentam nos equipamentos da assistência. Constatouse que as referências técnicas são vagas e apontam caminhos, não prescrevendo atividades específicas. Dessa forma, o profissional precisa lançar mão de recursos próprios para alcançar os objetivos previstos na Política Nacional de Assistência Social, adotando uma postura criativa e inventiva.

Palavras-chave: Psicologia Social e do Trabalho, condições de trabalho, Política de Assistência Social, Sistema Único de Assistência Social.

\section{La Actuación del Psicólogo en la Asistencia Social Brasilena}

\section{Resumen}

La presencia de psicólogos en la asistencia social brasileña ha sido cada vez mayor, pero la realidad de la psicología en ese contexto todavía está rodeada por imprecisiones e incertidumbres acerca de los papeles y la identidad de ese profesional en un contexto social de pobreza y necesidades materiales. El presente artículo analiza el trabajo del psicólogo en el ámbito de la asistencia social considerando las condiciones de trabajo de estos profesionales. La encuesta contó con la participación de 1100 psicólogos de todas las regiones de Brasil que respondieron a un cuestionario en línea abarcando cuestiones sociodemográficas y laborales. Los resultados muestran que los psicólogos son mal remunerados, tienen una carga horaria extensa y no están preparados técnicamente para lidiar con las cuestiones que se presentan en los equipos de la asistencia. Se constató que las referencias técnicas son vagas y apuntan caminos, no prescribiendo actividades específicas. De esta forma, el profesional necesita lanzar recursos propios para alcanzar los objetivos previstos en la Política Nacional de Asistencia Social, adoptando una postura creativa e inventiva.

Palabras clave: Psicología Social y Laboral, condiciones de trabajo, Política de Bienestar Social, Sistema Único de Asistencia Social.

The history of social welfare in Brazil took the current format a little more than ten years ago, however, it has gradually gained ground since the 1930s when the National Council of Social Service (Conselho Nacional de Serviço Social [CNSS]) was created. In the following decade the Brazilian Legion of Assistance (Legião Brasileira de Assistência [LBA]) was established, which was intended to support the families of soldiers who had fought in World War II. After the end of the war, this organization began to provide aid to needy families in general. In 1977 the Ministry of Social Security and Social Assistance was instituted and 11 years later, in 1988 the Constitution of the Republic was promulgated.

Prior to this, the concept of social welfare referred to the idea of need and charity, since the state did not take social actions to promote assistance to the underprivileged, which happened only through isolated practices by private institutions, without continuity or regulation. In this way social welfare was related to a legacy of welfarism and philanthropy (Senra \& Guzzo, 2012). At that time, the denunciations related to the poverty of some social strata without state intervention pressured the political class to take measures to guarantee the rights of citizens in situations of vulnerability (Oliveira, Dantas, Solon, \& Amorim, 2011).

The Federal Constitution of 1988 sought to convert this reality, ensuring social protection to Brazilian citizens through social welfare that was operationalized for preventing the incidence of risks, reducing harm and guaranteeing citizen protection; for social surveillance, which consists of the territorial analysis of the protective capacity of the families; and for the defense of rights and guarantee of full access to socio-welfare rights.

The idea then moved from lack to the idea of vulnerability (Bastos \& Rocha, 2011), with the Constitution being a milestone in the attempt to guarantee social rights for all Brazilians. 
Through it, the Social Security - Public Health - Social Welfare trio was established in Brazil, aiming for a more equitable system of social protection for the population.

Even so, the consolidation of this policy only occurred in December 1993 with the enactment of the Organic Law of Social Assistance (Lei Orgânica de Assistência Social [LOAS]; Law No. 8.742, 1993) aimed at carrying out actions involved in this practice. This law characterizes social welfare as a non-contributory and inalienable right for any citizen in situations of vulnerability and without social protection and reveals an attempt to modify the panorama of public social welfare policies in Brazil. The fruit of this movement was the creation of the National Social Assistance Policy (Politica Nacional de Assistência Social [PNAS]), which is discussed in this article.

The new policy aimed to guarantee the right to citizenship and was prepared to overcome welfarism, guaranteeing the survival of the low income community, the reception and provision of human needs, the development of family, individual and social autonomy and the survival of risk circumstances (Afonso, 2008).

This brought about a new ordering of social welfare policies and, in 2005, the Unified Social Assistance System (Sistema Único de Assistência Social [SUAS]) was created, implementing actions that were divided into services, benefits, programs and projects. The SUAS operates through two elements that are articulated: the socio-assistance, which concerns the guarantee of rights to users, and the socio-education, which aims at social inclusion of the user, since the individual is understood as not only a subject of rights, but also a subject of the culture. In this way, the SUAS aims to promote the autonomy of families and individuals and promote citizenship and quality of life (Afonso, Vieira-Silva, Abade, Abrantes, \& Fadul, 2012). It is guided by administrative decentralization, social participation, territorialization of the services, democratic control and family-centered guidance (Afonso, Hennon, Carico, \& Peterson, 2013).

In order to ensure the social transformation process that the SUAS delineates, it acts on the conditions that generate vulnerability based on strategies derived from its guiding principles (Romagnoli \& Moreira, 2014). For this, the SUAS is subdivided into two poles: the first refers to Basic Social Protection (BSP), aimed at individuals and groups in a situation of social vulnerability, but with links to social belonging. Basic Social Protection acts on a protective, preventive and proactive level, in an attempt to contain the rupture of family bonds and the violation of rights. This pole includes programs such as the Integral Family Protection and Assistance Service (Serviço de Proteção $e$ Atendimento Integral à Família [PAIF]), which provides care and support to families, and operates the Continuous Benefit Provision (Benefício de Prestação Continuada [BPC]) and the Family Allowance Program (Programa Bolsa Família [PBF]).

Basic Social Protection is represented by the Social Assistance Referral Centers (Centros de Referência de Assistência Social [CRAS]) that provide care to communities, families and people with low-incomes and are the headquarters of the BSP. These are responsible for managing and organizing devices, groups and institutions, articulating them and promoting work directed toward the target population.

The CRAS play a central role in the area by providing continuous services, such as reception, referrals to the social protection network, socio-educational monitoring, orientation and guarantee of rights. The service that anchors the CRAS is the Service of Protection and Integral Assistance to the Family (Serviço de Proteção e Atendimento Integral à Família), which consists of social work with the purpose of strengthening the family's protective function, improving their quality of life, preventing rupture of the bonds and promoting access to rights.

The second pole constitutes Special Social Protection (SSP) and aims to serve individuals and communities where there have been violations of rights or where the social bonds are threatened, with measures taken to reestablish broken bonds. Special Social Protection deals with issues of medium and high complexity, such as exploitation and child labor, violence 
against children, adolescents, the elderly and women and the institutional reception of adolescents in compliance with Assisted Living.

The Specialized Social Assistance Reference Center (Centro de Referência Especializado de Assistência Social [CREAS]) is a medium-complexity public facility designed to protect individuals and families that have had their rights violated but whose family and community bonds have not been broken. It offers services to combat violence, abuse and sexual exploitation of children and adolescents; social protection service for adolescents in compliance with socio-educational measures and social protection services for older adults and women that have been victims of violence; services for individuals suffering from withdrawal from family life, weakening of the bonds and physical or psychological violence.

The reference teams, in both cases, are composed of professionals with diverse training, among which is the psychology professional. However, when the psychology profession was regulated, the legislation demarcated three major areas of psychology: clinical, school and industrial psychology and, historically, the psychologist went on to perform the function of psychotherapist (Ferreira, 2017), which indicates, in principle, a lack of preparation for the practice of the psychologist in these teams.

At its start, psychology in Brazil had a predominantly biomedical nature, following a psychotherapeutic model that served only the most elitist population of society. Directed toward the more affluent social groups, psychology copied the model of medical care, in a context of private and liberal-psychotherapeutic care. While psychologists constituted their bases and demarcated their field of action, they were consolidated as liberal and elitist professionals, who did not work with social questions. Thus, until the 1980s, the work of the psychologist in Brazil was mostly linked to the demands of the middle and upper class populations, without having significant participation in the lower classes (Oliveira et al., 2014).

However, the discussion about the insertion of psychology into the public policy scenario is not new. This dates back to the 1970s, when some studies showed the saturation of the labor market of the autonomous professional psychologist in Brazil. In addition, they also questioned the theoretical-methodological limitations of the psychology practice in the midst of large social inequalities (Yamamoto, 2007). This scenario began to change from practices that emerged from certain needs of society and the psychologists were called to provide a more effective insertion in the communities. Because it was a new area of insertion for psychology, there were difficulties in the demarcation of the role to be exercised and in the professional identification of the psychologist in this context, problems that seem to persist to the present day.

Although the Reference Centers (CRAS and CREAS) are, in their definition, constituted by interdisciplinary teams, including psychologists, the profile of the psychology professional in social assistance can only be traced back to 2006, with the publication of the Basic Operational Norm of Human Resources of the SUAS (Norma Operacional Básica de Recursos Humanos do SUAS [NOB-RH/SUAS]; Biasus \& Franceschi, 2015). Nevertheless, challenges for psychology persist with regard to its insertion in the social welfare teams, with no pre-defined work models or consensus on ethical-political actions in the area.

The official document that regulates the activities to be developed in the CRAS by the technical team is the Technical Guidance Guide (Guia de Orientação Técnica [SUAS] $n^{\circ} 1$; Ministério do Desenvolvimento Social e Combate à Fome [MDS], 2005). According to the document, the activities to be developed by the team, including the psychologist, are social surveillance (construction of indicators and indices of vulnerability situations), mapping of the area (survey of services, programs and benefits that exist in the area or nearby), active search (identification of nearby users who need the services), reception, referrals, home visits, monitoring, networking and groups with socio-educational activities.

In the CREAS the prescribed activities are reception, psychosocial monitoring (identifi- 
cation of implicit and explicit demands), interviews, home visits, group interventions (construction and exchange of knowledge, coping with situations experienced, strengthening and identification of potentialities and strengthening of autonomy and bonds), network articulation, information recording (evaluation of information important to the understanding of the case through: (a) charts, which contain specific information about the requirements, progress, challenges and planning and (b) technical reports, which should contain information observing the rules of the production of documents in psychology), team meetings and case study meetings. It is important to highlight that the document states that it is necessary to construct professional practices based on the analysis of the cultural, social, economic and political context in which families are inserted, which leads to the understanding that these practices are constantly being constructed (MDS, 2011) .

In 2016, the Technical Note No. 001/2016, which deals with guidelines on the preparation of documents in the SUAS context (reports and recommendations, for example), was constructed by the National Psychology Commission on Social Assistance (Comissão Nacional de Psicologia na Assistência Social [CONPAS]). Elaborated by psychologists to guide the actions of psychologists working in the CRAS and/or CREAS, the Technical Note suggests that the preparation of documents be carried out in a joint and interdisciplinary way; reminding that psychology works in health activities, social services and education, according to the Brazilian Classification of Occupations (Classificação Brasileira de Ocupações [CBO]), and in the monitoring and orientation of individuals, groups and institutions, as well as in the coordination of teams and activities related to social welfare. The Technical Note also reaffirms that the psychologist should screen cases, define working methodologies, facilitate groups, provide emotional support, develop educational projects, guide changes of behavior, investigate people and situations, act in health prevention and propose interventions (Conselho Federal de Psicologia [CFP], CONPAS, 2016).
Although the Brazilian Nation Health System (Sistema Único de Saúde [SUS]) has already gained a larger place in psychology training due to the insertion of the psychologist into the area of public policies being performed through the SUS (Oliveira et al., 2017), the SUAS has not yet achieved the same space and this has generated a weak theoretical-methodological contribution for the professionals that work in the policies of social welfare.

The relationship between psychology and social welfare is still incipient. Academic training is a crucial point to foster discussions about psychological practices in the SUAS and this is only possible with the implementation of disciplines that promote theoretical discussions and instrumentalize students technically to practice in that field. In addition, there is a need for the approximation of teachers and students with the socio-welfare networks and communities (Gomes \& Dimenstein, 2016).

Miron and Guareschi (2017) highlighted that the social commitment of psychology can be only a politically correct discourse, however, it does not transform into effective practices for society and for communities, therefore, social commitment must go beyond the discourse, overcoming theories and arriving at the reality.

Although the SUAS has absorbed a large number of psychology professionals since its implementation, one of the major problems that this professional category faces in the area of social assistance is the devaluation of the profession, which occurs due to low remuneration, precarious working conditions and fragile employment contracts. An increase in outsourcing was observed as a way of contracting professionals in the public sector (Macêdo, Heloani \& Cassiolato, 2010), to the detriment of filling vacancies through public job examinations.

\section{Objectives}

The aim of the study was to analyze the work of psychologists practicing in the CRAS and CREAS in the fulfillment of public social welfare policies, considering the working conditions of these professionals. Specifically, the 
study aimed to map the presence of psychologists in the mentioned teams, to construct their sociodemographic profile, to characterize the activities carried out and to investigate the working conditions, academic training and means of insertion into the public service.

\section{Method}

\section{Participants}

A total of 1,100 psychologists working in the SUAS at the time of the study participated. The participants were invited to respond to an online questionnaire. The main way the professionals were contacted was through the email addresses present in the MDS website, and the method of divulgation of the study was through email, closed groups in social networks and groups of cellular applications.

\section{Instruments}

The instrument used for the data collection was a questionnaire designed by the authors, composed of 57 questions that inquired about sociodemographic and labor issues, developed through the Google Forms platform. Of the total, 7 questions addressed sociodemographic issues and 50 labor issues, assessing the frequency of activities, working conditions, interpersonal relationships in the team, results of work performed, workload and the place of attending the public, as well as opinions on the services provided. Depending on the type of question some allowed multiple answers.

\section{Data Collection and Analysis Procedure}

For the data collection, the questionnaire was available online for 7 months between 2016 and 2017. Psychologists that were working in Reference Centers (CRAS or CREAS) during the data collection period were invited to participate.

To perform the analysis, the answers to the open questions were standardized, creating categories according to the responses received. There was also a need to create new categories in some questions due to the repetition of similar answers in the open questions. The data were then submitted to statistical analysis using the SPSS (Statistical Package for the Social Sciences), version 24 for Mac, statistical package.

The study was appraised and approved by the Research Ethics Committee, under authorization number 1.865.467.

\section{Results}

Table 1 represents the results found in the study with the absolute frequencies $(f)$ and percentages.

Regarding the sociodemographic profile of the sample, $84.1 \%$ of the participants were women, with a mean age of 30 years $(S D=9.89$ years) and mean time since graduation of 6 years $(S D=5.81)$; the majority graduated from private universities $(73.3 \%)$, had worked in the SUAS for more than 5 years $(20.7 \%)$ and worked between 30 and 40 hours per week (80.7\%).

Considering the geographic location, the highest number of study participants came from the Northeast region $(f=351)$, followed by the Southeast region $(f=336)$, South region $(f=226)$, North region $(f=104)$ and the Central-West region $(f=83)$. Considering the states, São Paulo had the largest number of participants, followed by Minas Gerais, while the states with the lowest participation, in absolute numbers, were Amapá and Roraima.

It was found that $71 \%$ of the subjects were up to 35 years of age, while $24 \%$ were aged 36 years and over. Regarding salaries, the majority of the respondents $(74.6 \%)$ indicated a monthly remuneration between $\mathrm{R} \$ 1,001$ and $\mathrm{R} \$ 3,000$, which was less than 4 minimum salaries at the time of the study. Those that earned between $\mathrm{R} \$ 3,001$ and $\mathrm{R} \$ 5,000$ represented $20.8 \%$, and only $4.6 \%$ were in the extremes, having less than $\mathrm{R} \$ 1,000$ or more than $\mathrm{R} \$ 5,000$ as their monthly salaries.

In relation to initial and continuing training, $52.6 \%$ of the participants had a specialization, $39.8 \%$ an undergraduate degree and $7.5 \%$ a graduate degree ( $8 \mathrm{PhD}$ and $75 \mathrm{MSc})$. The mean time since graduation was 6 years $(S D=5.81)$, with $37 \%$ of the sample having between 2 and 5 
Table 1

Professional Characteristics of the Sample Studied $(N=1100)$

\begin{tabular}{|c|c|c|c|}
\hline Variables & Levels & $f$ & Percentage \\
\hline \multirow{2}{*}{ Gender } & Female & 925 & $84.10 \%$ \\
\hline & Male & 175 & $15.90 \%$ \\
\hline \multirow{6}{*}{ Age group } & Did not respond & 53 & $5.00 \%$ \\
\hline & From 20 to 25 years & 132 & $12.00 \%$ \\
\hline & From 26 to 30 years & 369 & $33.00 \%$ \\
\hline & From 31 to 35 years & 286 & $26.00 \%$ \\
\hline & From 36 to 40 years & 132 & $12.00 \%$ \\
\hline & From 41 years & 128 & $12.00 \%$ \\
\hline \multirow{5}{*}{ Geographical region } & $\mathrm{N}$ & 104 & $9.45 \%$ \\
\hline & $\mathrm{NE}$ & 351 & $31.90 \%$ \\
\hline & $\mathrm{CW}$ & 83 & $7.50 \%$ \\
\hline & SE & 336 & $30.54 \%$ \\
\hline & $\mathrm{S}$ & 226 & $20.54 \%$ \\
\hline \multirow{4}{*}{ Time since graduation } & Less than 2 years & 56 & $5.00 \%$ \\
\hline & From 2 to 5 years & 406 & $37.00 \%$ \\
\hline & From 6 to 9 years & 330 & $30.00 \%$ \\
\hline & From 10 years & 308 & $28.00 \%$ \\
\hline \multirow{3}{*}{ HEI } & Federal & 192 & $17.50 \%$ \\
\hline & State & 102 & $9.30 \%$ \\
\hline & Private & 806 & $73.30 \%$ \\
\hline \multirow{4}{*}{ Remuneration } & Below $\mathrm{R} \$ 1,000$ & 12 & $1.10 \%$ \\
\hline & Between $\mathrm{R} \$ 1,001$ and $\mathrm{R} \$ 3,000$ & 821 & $74.60 \%$ \\
\hline & Between $\mathrm{R} \$ 3,001$ and $\mathrm{R} \$ 5,000$ & 229 & $20.80 \%$ \\
\hline & Over $\mathrm{R} \$ 5,000$ & 38 & $3.50 \%$ \\
\hline \multirow{4}{*}{ Education } & $\mathrm{PhD}$ & 8 & $0.70 \%$ \\
\hline & MSc & 75 & $6.80 \%$ \\
\hline & Specialization & 579 & $52.60 \%$ \\
\hline & $\mathrm{BSc}$ & 438 & $39.80 \%$ \\
\hline \multirow{7}{*}{ Time in SUAS } & Up to 6 months & 178 & $16.20 \%$ \\
\hline & Between 6 months and 1 year & 127 & $11.50 \%$ \\
\hline & Between 1 and 2 years & 196 & $17.80 \%$ \\
\hline & Between 2 and 3 years & 146 & $13.30 \%$ \\
\hline & Between 3 and 4 years & 142 & $12.90 \%$ \\
\hline & Between 4 and 5 years & 83 & $7.50 \%$ \\
\hline & More than 5 years & 228 & $20.70 \%$ \\
\hline \multirow{4}{*}{ Working hours } & 40 hours & 462 & $42.00 \%$ \\
\hline & 30 hours & 426 & $38.70 \%$ \\
\hline & 20 hours & 177 & $16.10 \%$ \\
\hline & Others & 35 & $3.18 \%$ \\
\hline
\end{tabular}


years since graduation. However, a considerable portion had graduated more than 10 years previously (28\%).

The specialization most present among the participants was the clinical area (25\%); mental health ranked second with $17 \%$ and only $6 \%$ specialized in public policies. The majority of the psychologists had graduated from private institutions $(73.3 \%) ; 17.4 \%$ studied in federal universities and $9.3 \%$ in state universities.

Regarding marital status, the majority of the participants were single $(51.5 \%)$, followed by married $(32.9 \%)$ and the remainder divided between those with a stable union, widowed and divorced.
Regarding the work data, the first to be highlighted is the level of complexity of social protection where the participants practiced. Of the 1,100 respondents, $67 \%$ worked in the Basic Social Protection (CRAS) level and 33\% in the Special Social Protection of Medium Complexity (CREAS).

Regarding the form of entrance into social assistance of the participants of this study, a high index of participants was found: $56.8 \%$ of the participants went through a public job examination and had a statutory contract. There was a similarity, in percentage terms, between the participants that work in BSP and those that worked in SSP, being $58.1 \%$ in the CRAS and $54.2 \%$ in the CREAS (Figure 1).

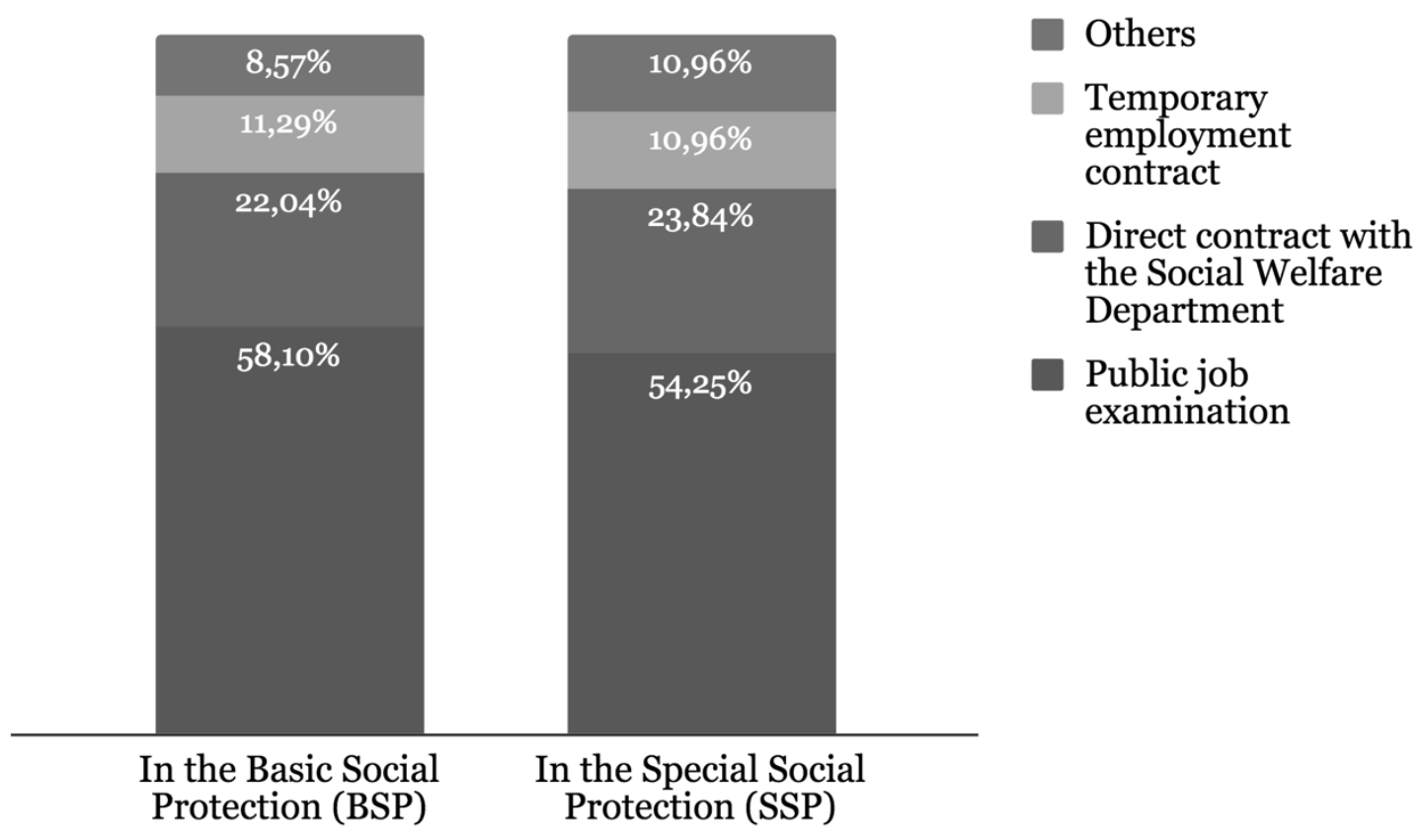

Figure 1. Type of employment contract.

Considering the activities developed by the participants, the most cited were psychosocial monitoring, registration of activities, action planning and reception. Network articulation and socio-educational activities also appeared to be present in high percentages (above 70\%). Clinical care, although not provided for in the technical norms, appears in the data collected, however, with low frequency (11.27\%), as can be observed in Figure 2.
Regarding the frequency of the activities, the daily activity that most stood out was the recording of activities, followed by the activities of reception and psychosocial monitoring. The majority of the activities were carried out on a daily or weekly basis, with the activities that, according to the majority, were never performed highlighted as being: clinical care $(82 \%)$, territorialization $(41 \%)$, social surveillance $(61 \%)$ and specialized monitoring (38\%). 


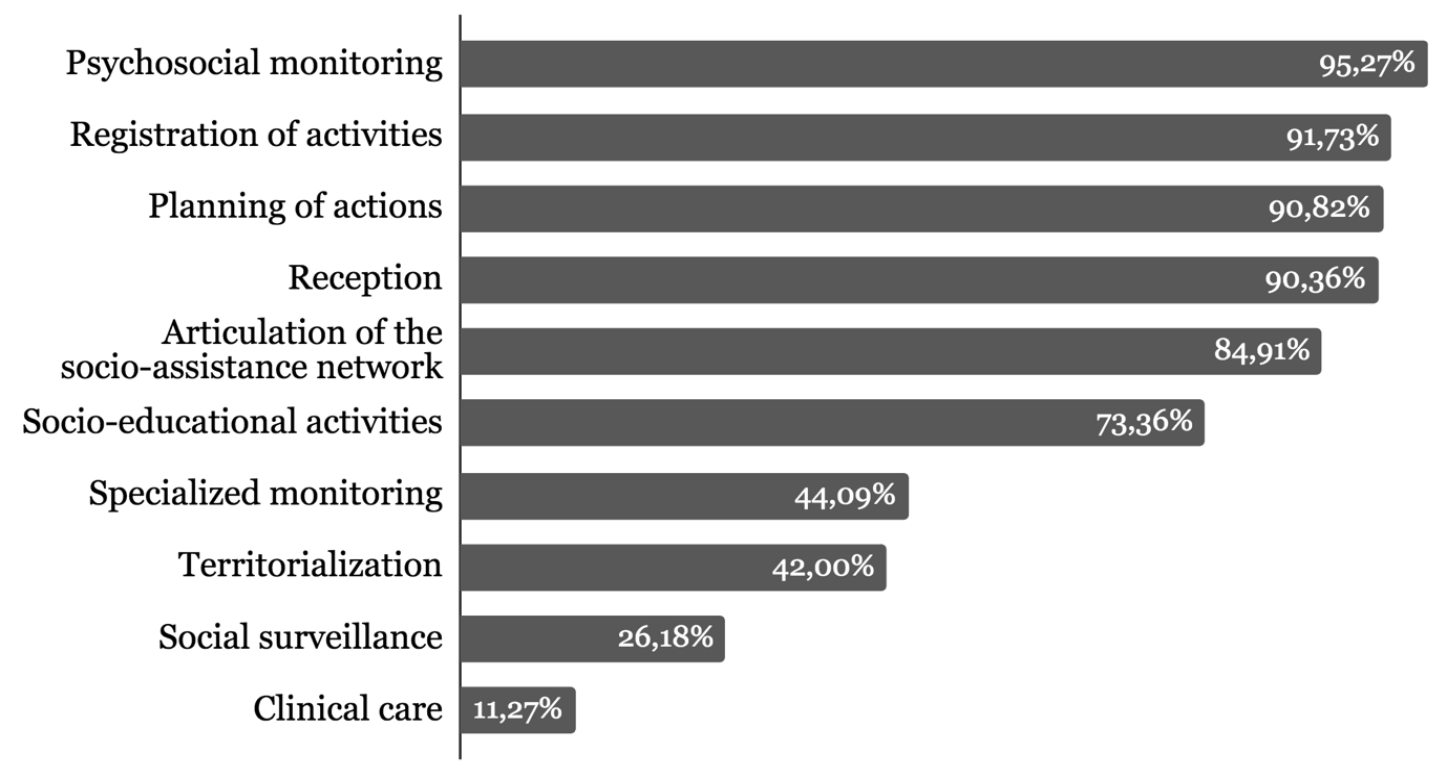

Figure 2. Activities performed.

This study also investigated the assessments that professionals made of their work. The majority of respondents considered the working conditions to be regular (41\%), although a large number $(22.5 \%)$ consider them to be poor or precarious. Only a small percentage $(1.2 \%)$ said these conditions were excellent. The psychologist's relationship with the community was considered very good by $45 \%$ and satisfactory by $30 \%$ of the sample. In the question regarding the psychologist's relationship with the team there was a slight variability among the percentages, with the majority of the sample (34\%) considering this relationship to be very good. Regarding the results of the work, $43 \%$ considered them satisfactory, as can be seen in Figure 3.

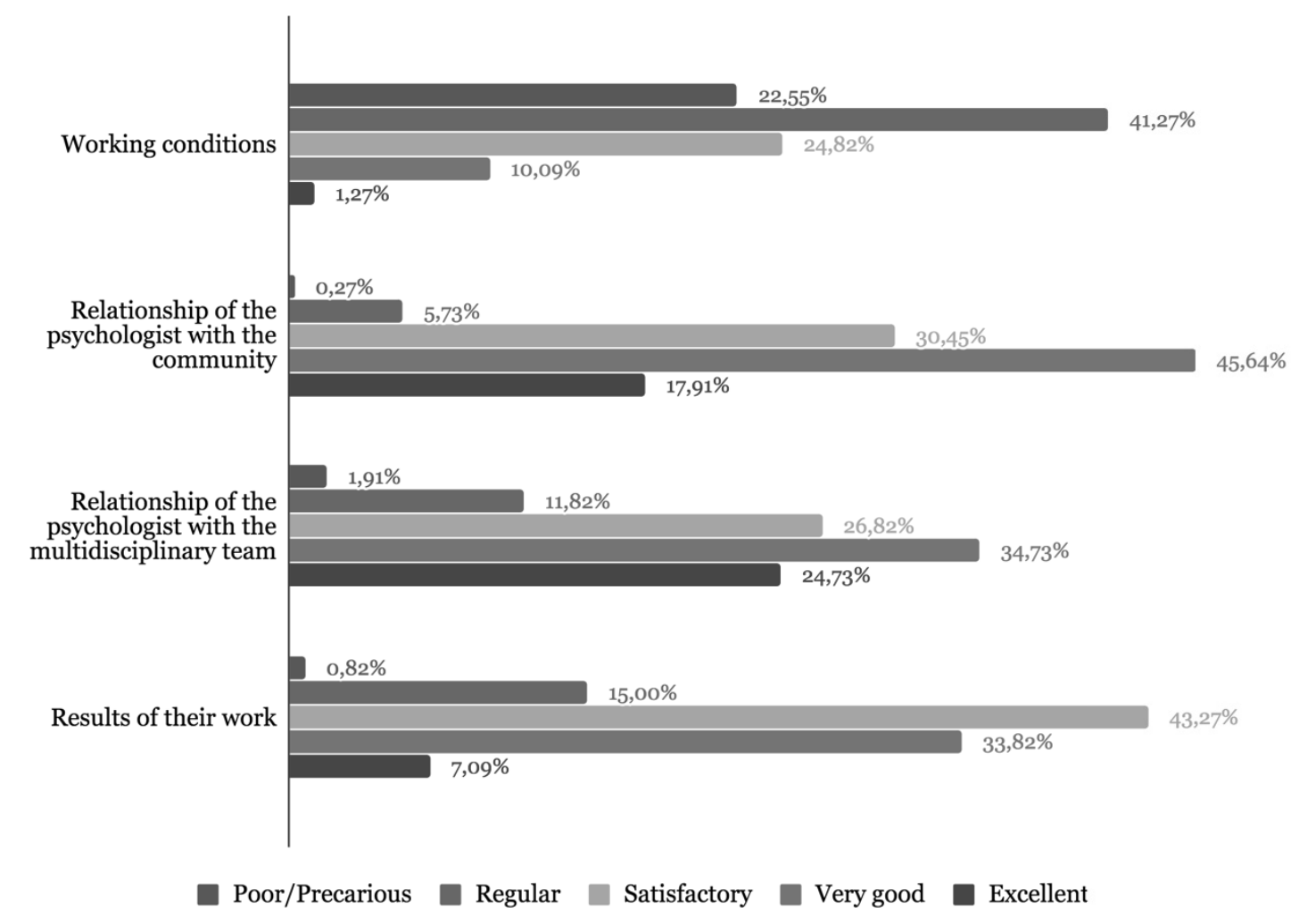

Figure 3. Participant's evaluations regarding aspects of the work. 
The five main results of the psychologists' work in these teams, according to the professionals' reports, were the strengthening of family and community bonds; defense of rights; develop- ment of family, individual and social autonomy; enhancement of users' psychosocial resources and contribution to the exercise of citizenship and autonomy, as shown in Figure 4.

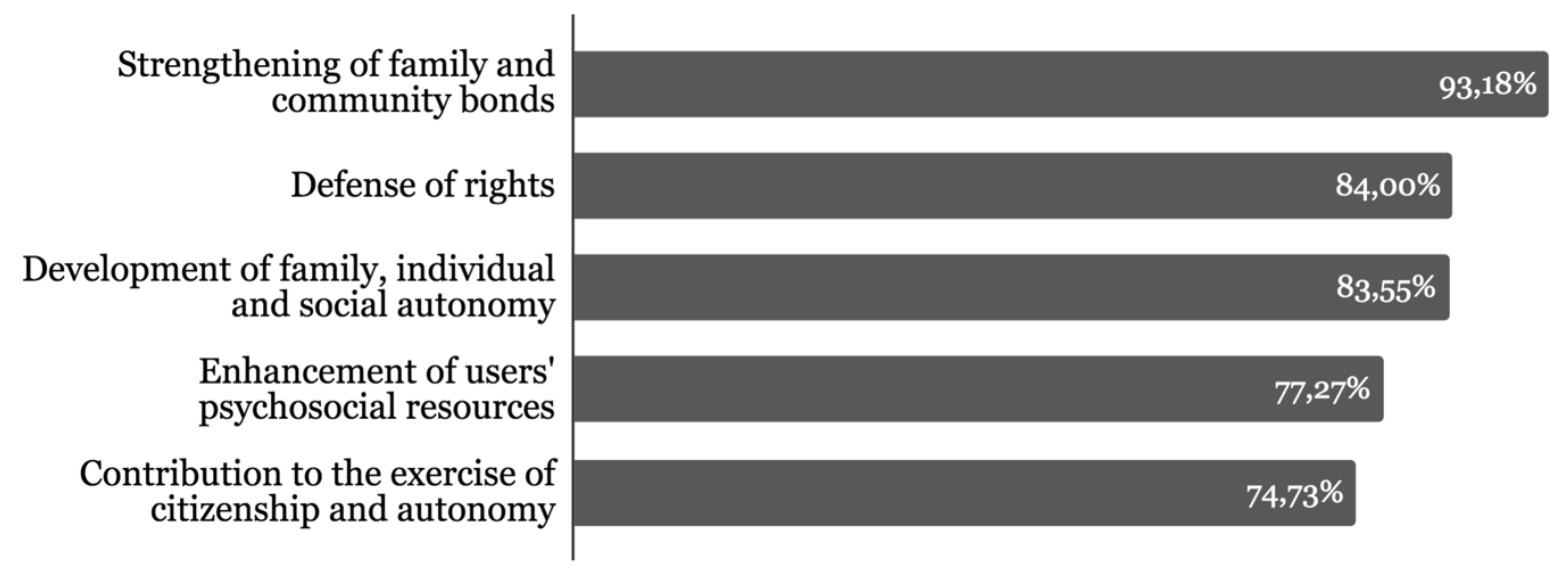

Figure 4. Main results of the work in the context of the SUAS.

Among the options presented, ranging from fields of study of social psychology to approaches of psychology, the two main theoretical references used as support for the development of the work in the SUAS were Social Psychology $(33 \%)$ and Community Social Psychology $(30 \%)$. However, $78.5 \%$ of the professionals reported that they had no theoretical background in their undergraduate courses in social policies.

Difficulties at work seemed to be many. The participants reported that the biggest obstacle faced in the SUAS was low wages (54\%). In addition to this obstacle, the number of families attended was greater than the capacity (48\%), there was no transport for home visits $(42.9 \%)$, political interference in the work (42.8\%) and an overload of work $(42.2 \%)$ and the infrastructure conditions were precarious (39\%).

One of the questions asked whether the work developed by the psychologists in the SUAS corresponded to what the technical references recommend. The majority answered yes, however, a considerable portion, $17.5 \%$, said their work did not match what was prescribed.

\section{Discussion}

One of the most significant aspects of the study was the considerable number of psychol- ogists who held the position having undergone a public job examination. This data is relevant, considering that the PNAS is considered a new policy and many of the municipalities are still hiring professionals through temporary contracts or outsourced companies, as shown in the study by Macedo et al., 2011. This highlights the growth in the number of workers with permanent contracts, which an aspect that is extremely relevant and beneficial to the field, since fragile and/or precarious employment relationships fragment the actions and produce a high rate of turnover (Bastos, Gondim, \& Rodrigues, 2010; Seixas, 2009), so that the professionals spend little time on the team, leaving as soon as they find better working conditions and salary. The high rate of turnover of professionals in the SUAS compromises the actions, since it weakens the formation of bonds with the users and makes it impossible to have a satisfactory interaction with the work team.

Taking into consideration the data collected by Macedo et al. (2011), who found that statutory psychologists accounted for $27.0 \%$ of those working in the CRAS and $37.6 \%$ in the CREAS, it can be affirmed that PNAS and SUAS have implemented fruitful changes regarding the employment contracts and that there were not only improvements in the BSP, but also in the SSP, 
with the amount of permanent contract psychologists having increased in the CREAS in this study.

A striking aspect to be highlighted is that all the psychologists who earned from $\mathrm{R} \$ 5,000$ held the position having undergone a public job examination, and of those who had incomes between $\mathrm{R} \$ 4,001$ and $\mathrm{R} \$ 5,000,96 \%$ had also been through a public job examination. It was observed, therefore, that there is a correlation between the employment contract and income.

The data obtained regarding the pay range show that there is a need for a salary revision in these public teams. This result corroborates the data found by Martins, Matos, and Maciel (2009), Oliveira et al. (2011) and Santos, Monteiro, Torres, Sousa, and Coelho (2014).

The majority of the professionals of this team $(71 \%)$ are in an adult-young person age group (up to 35 years of age), however, it is interesting to note that a considerable proportion of the subjects, $24 \%$, were more than 35 years of age. In addition, $12 \%$ of the subjects were over the age of 40 , suggesting a strong presence of more experienced professionals and the tendency to seek more stable positions.

Regarding the evaluations that the professionals made of their work, it is emphasized that more than $85 \%$ considered the relationship with the multidisciplinary team from satisfactory to excellent, which indicates that the joint practice is being better administered by some of the public policy psychologists. The work that was previously limited to a practice of isolated consultation has today been reinvented and exercised in different environments.

Regarding the results of the work, almost $85 \%$ evaluated this from satisfactory to excellent, suggesting that there has been a reformulation in the concept of results of these professionals, who previously said that they did not see the effects of their work due to bureaucratization, change of management and high turnover in the context of the SUAS.

The fact that the majority of the participants in this study had a lato sensu (52\%) graduate qualification, and only $7.5 \%$ had an MSc or $\mathrm{PhD}$ indicates that the long hours worked by the
SUAS professionals may hinder their entry into strictu sensu graduate programs. In addition, there was no incentive from the municipalities, which do not differentiate professionals with higher academic qualification, in terms of salary.

The majority of the psychologists had graduated from private institutions (73.0\%), a result that is not surprising, since similar data were also highlighted by Malvezzi, Souza, and Zanelli (2010), who found a comparable percentage $(75.7 \%)$ of professionals graduated from private institutions. This result shows that there is a greater offer of the course in private colleges, as well as easier access for the population, as a result of student financing programs.

No positive correlation was found between the graduation origin of the participants and the theoretical basis for the work in the SUAS. All HEIs were classified as unsatisfactory regarding the theoretical basis for work in social policies. This data confirms what Seixas, Costa, Oliveira, Costa, and Yamamoto (2016) found in a study on the curricularization of contents of social policies in undergraduate psychology courses in Brazil. Another study carried out by Costa and Yamamoto (2016) also revealed that this gap does not only exist in the undergraduate courses, but also in the stricto sensu graduate programs.

The academic training was deficient in public policies content, confirming the data found by Biasus and Franceschi (2015), Macêdo, Alberto, Santos, Souza, and Oliveira (2015), Oliveira et al. (2011) and Oliveira et al. (2014). Thus, it is important to reflect on the need to implement academic content that will equip psychologists to practice in the area of social policies.

The majority of the activities developed by psychologists are covered in the technical guidelines, however, it was expected that more psychologists would be involved in Social Surveillance. This is defined as the construction of the profile of the community and is essential for the performance of good social welfare work, as the professionals need to know the reality and the needs of the area where the centers of reference are. In the study $61 \%$ reported never having performed any activities related to this. This also 
highlights the activity of territorialization, understood as the mapping of the community institutions that can act together for the benefit of the families. However, $42 \%$ said they did not carry out territorialization. It was expected that more psychologists would be engaged in investigating the territories.

On the other hand, the provision of psychotherapeutic care present in the results is not in accordance with the SUAS proposal. The references only indicate preliminary listening and reception of the users, from a broad clinical perspective. When perceiving the need for other types of monitoring, such as mental health, professionals should refer the users to the health services, however, the reality does not seem to favor this referral, since not all municipalities have health services that work satisfactorily. In addition, psychology professionals working in the SUS also do not perform psychotherapeutic clinical care, which leads to more profound reflections: whether or not clinical care should be provided in the SUAS and what type of clinical care should be considered. If the answer to the first question is positive, who within the public policy area would fulfill this role? How should this be carried out in the public policy area?

Regarding the results of the psychologist's work in the social assistance team shown above, the data are important, since one of the most important targets of the PNAS is the strengthening of bonds and the defense of rights for the consequent reduction of risk situations and social vulnerabilities ( $93 \%$ and $84 \%$ respectively reported presenting these results). Thus, this finding suggests that the Policy has achieved its main goal. Despite this, the difficulties reported indicate that the psychologist's working conditions in the SUAS are far below what is necessary for the development of work of excellence.

The predominance of females in the study sample (84\%) was similar to the result found by Bastos et al. (2010) in the sample of their study on the characterization of the profession, where $83.3 \%$ were female. The authors discuss the gender of the profession and claim that psychology is an eminently female profession. In addition, the percentage of women identified in the sample of this study is close to that found by Macedo et al. (2011), who specifically investigated SUAS psychologists and found $89.6 \%$ of the professionals to be female.

Although this study had wide coverage and a large sample, there are limitations regarding the extent of, for example, professionals in the North region of the country. This location was the most difficult to access for data collection, since the contacts were difficult even with the relative ease that the internet provides. It is possible that these professionals do not have stable employment contracts, as presented by the majority, with probable interregional variations. The participation of the South and Southeast was significant, which may suggest that these regions have made progress regarding the way the professionals are contracted, while other regions do not seem to have this reality.

The form of data collection via the Internet, although being advantageous in terms of scope, comprehensiveness, low cost, flexibility and convenience for respondents, can generate limitations on the reliability of the data, since the researcher is not face-to-face with the participants. Furthermore, impersonality can also hinder the process (Gonçalves, 2008).

It is hoped that the implications of this study are linked to the promotion of impacts in the academic context regarding the revision and reformulation of the curricular bases, including social policy content, and that the state fosters stable working relationships so that the professional can not only have the conditions to strengthen the community, but also develop as an individual and professional. Another possible implication of this study is a review of the remuneration of the professionals, which is also something that needs to be carried out rapidly, as the SUAS loses qualified professionals because of the low remuneration it offers.

\section{Conclusions and Considerations}

This study verified that the profile of the psychology professional that works in the SUAS is that of a female professional, who went through a public job examination, has between 2 
and 5 years since graduating, an income between $\mathrm{R} \$ 1,001$ and $\mathrm{R} \$ 3,000$, and works 40 hours per week.

It is considered that the salary range prevailing in the sample of this study is incompatible with the life investment of 5 years in an undergraduate course and more time in post-graduate lato or stricto sensu courses. Given the poor remuneration, it is possible that work in the area of social assistance is seen only as a temporary phase, while the professional continues to seek better opportunities.

What can be inferred from the results found is that the psychologist's work in the Brazilian social assistance team is partially in accordance with the guidelines prescribed for the practice in the SUAS. From the market and professional perspective, it can be affirmed that there were gains for psychology with the welfare policy, since this provided new fields of action for the professionals. Inserting the psychologist into the basic teams of the SUAS, opened up more space for the exercise of the profession and expanded the practice and scope of psychology. The work of psychologists in the SUAS allows populations in situations of risk and social vulnerability access to psychology.

Also in relation to the work, the results show that much of what is predicted in terms of activities in the SUAS teams is carried out by the professionals, although there are still failures in relation to some prescribed actions. In addition, the professionals remain in doubt about which tasks are their responsibility, resulting from inadequate social policy training and the lack of working models in this context.

It can be seen that the psychologist is not technically and operationally prepared to deal with issues in this field, especially those related to conditions of poverty, material needs and situations of risk and social vulnerability. This occurs because the academic training is not satisfactory and does not instrumentalize the professional to deal with these demands. The curricula of higher education institutions need to encourage the discussion of public policies, social issues and more specifically the National Social Assistance Policy (Seixas et al., 2016).
Consequently, it also does not cover the SUAS and the inclusion and work of psychologists in the CRAS and CREAS or their role in the area of social welfare. The professional can be better prepared when the institutions include not only content on public policies, but also discussions and critical reflections on this reality in their curricular matrices.

Based on the finding that the psychologist's work in the social assistance teams studied is partially in accordance with that prescribed by the guidelines for the work in the SUAS, the following reflections are also proposed: does carrying out what corresponds to the norms, regulations and technical references for the psychologist's work in the context of social assistance signify doing good work? Does the prescribed work apprehend the reality of a continental country with such great differences and disparities in the reality? Would psychology effectively manage to obtain the content of these populations? Does the psychologist need to construct a new identity to work within the context of social welfare? Do the norms encompass the reality of the psychologists in the SUAS and the community at social risk that they attend?

It is understood that the professional practice is not just the result of academic content and that the professional needs to go beyond this, in search of additional knowledge to what the university provides, however, the curriculum bases must cover content and knowledge on the subject, since currently the SUAS is one of the areas that absorbs more psychologists in Brazil.

From what has been presented in this article and the remaining issues, possibilities for further research and analysis regarding psychology in the field of social policies are opened, a process that must be continuous and dynamic.

\section{References}

Afonso, M. L. M. (2008). O que faz a psicologia no sistema único da assistência social? Jornal do Psicólogo, 91(25), 14. Retrieved from http:// www.crpmg.org.br/CRP2/IMGSsite/File/jp91certopdf.pdf 
Afonso, M. L. M., Vieira-Silva, M., Abade, F. L., Abrantes, T. M., \& Fadul, F. M. (2012). A psicologia no Sistema Único de Assistência Social. Pesquisas e Práticas Psicossociais, 7(2), 189-199. Retrieved from https://ufsj.edu.br/portal2-repositorio/File/revistalapip/Volume7_n2/ Afonso,_Maria_Lucia_Miranda,_et_al.pdf

Afonso, M. L. M., Hennon, C. B., Carico, T. L., \& Peterson, G. W. (2013). A methodological approach for working with families in SUAS: A critical reading through the lens of citizenship [Special issue]. Psicologia \& Sociedade, 25, 80-90. Retrieved from http://www.scielo.br/pdf/ psoc/v25nspe/10.pdf

Bastos, A. V. B., Gondim, S. M. G., \& Rodrigues, A. C. A. (2010). Uma categoria profissional em expansão: Quantos somos e onde estamos? In A. V. B. Bastos \& S. M. G. Gondim (Eds.), O trabalho do psicólogo no Brasil (pp. 32-44). Porto Alegre, RS: Artmed.

Bastos, C. P. S., \& Rocha, M. L. (2011). Territórios em comum nas políticas públicas: Psicologia e assistência social. Psicologia \& Sociedade, 23(3), 634-636. Retrieved from https://dialnet. unirioja.es/descarga/articulo/3991953.pdf

Biasus, F., \& Franceschi, M. (2015). O psicólogo no CRAS: Características e desafios da atuação profissional. Revista de Psicologia da IMED, 7(1), 23-34. Retrieved from https://seer.imed.edu.br/ index.php/revistapsico/article/view/683/601

Conselho Federal de Psicologia, Comissão Nacional de Psicologia na Assistência Social. (2016). Nota Técnica $n^{\circ}$ 001/2016. Brasília, DF: Author. Retrieved from http://site.cfp.org.br/wp-content/ uploads/2016/04/Nota-Técnica-n ${ }^{\circ}$-001-2016CONPAS-CFP.pdf

Costa, A. L. F., \& Yamamoto, O. H. (2016). Políticas sociais na pós-graduação stricto sensu de psicologia. Estudos de Psicologia (Natal), 21(4). 456467. doi: 10.5935/1678-4669.20160044

Ferreira, J. L., Neto. (2017). Psicologia, políticas públicas e o SUS. São Paulo, SP: Escuta.

Gomes, M. A. F., \& Dimenstein, M. (2016). Serviço escola de psicologia e as políticas de saúde e de assistência social. Temas em Psicologia, 24(4), 1217-1231. doi: 10.9788/TP2016.4-03Pt

Gonçalves, D. I. F. (2008). Pesquisas de marketing pela internet: As percepções sob a ótica dos entrevistados. Revista de Administração Mackenzie, 9(7), 70-88.
Law No. 8.742. (1993). Dispõe sobre a organicidade da Assistência Social no território brasileiro. Brasília, DF: Author. (1993). Retrieved from http://www.planalto.gov.br/ccivil_03/LEIS/ L8742compilado.htm

Malvezzi, S., Souza, J. A. J., \& Zanelli, J. C. (2010). Inserção no mercado de trabalho: Os psicólogos recém-formados. In A. V. B. Bastos \& S. M. G. Gondim (Eds.), O trabalho do psicólogo no Brasil (pp. 85-106). Porto Alegre, RS: Artmed.

Macedo, J. P., Sousa, A. P., Carvalho, D. M., Magalhães, M. A., Sousa, F. M. S., \& Dimenstein, M. (2011). O psicólogo brasileiro no SUAS: Quantos somos e onde estamos? Psicologia em Estudo, 16(3). 479-489. doi: 10.1590/ S1413-73722011000300015

Macêdo, K. B., Heloani, R., \& Cassiolato, R. (2010). O psicólogo como trabalhador assalariado: Setores de inserção, locais, atividades e condições de trabalho. In A. V. B. Bastos \& S. M. G. Gondim (Eds.), O trabalho do psicólogo no Brasil (pp. 131-150). Porto Alegre, RS: Artmed.

Macêdo, O. J. V., Alberto, M. F. P., Santos, D. P., Souza, G. P., \& Oliveira, V. S. (2015). Ações do profissional de psicologia no centro de referência da assistência social. Psicologia: Ciência e Profissão, 35(3), 809-823. doi: 10.1590/19823703001632013

Martins, K. P. H., Matos, T. G. R., \& Maciel, R. H. O. (2009). Formação em psicologia e as novas demandas sociais: Relato dos egressos da Universidade de Fortaleza. Mal-Estar e Subjetividade, 9(3), 1023-1042. Retrieved from http:// pepsic.bvsalud.org/scielo.php?script $=$ sci_arttext\&pid=S1518-61482009000300013

Ministério do Desenvolvimento Social e Combate à Fome. (2005). Guia de Orientação Técnica - SUAS $N^{o}$ 1. Brasília, DF: Author. Retrieved from http://www.pg.pr.gov.br/cmas/wp-content/ uploads/2011/07/guia_orientacao_tecnica.pdf

Ministério do Desenvolvimento Social e Combate à Fome. (2011). Orientações Técnicas: Centro de Referência Especializado de Assistência Social - CREAS. Brasília, DF: Author. Retrieved from http://aplicacoes.mds.gov.br/snas/documentos /04-caderno-creas-final-dez..pdf

Miron, A. X., \& Guareschi, N. M. F. (2017). Compromisso social da psicologia e sistema único de assistência social: Possíveis articulações. Psicologia: Ciência e Profissão, 37(2), 349-362. doi: 10.1590/1982-3703000952014 
Oliveira, I. F., Amorim, K. M. O., Paiva, R. A., Oliveira, K. S. A., Nascimento, M. N. C., \& Araújo, R. L. (2017). A atuação do psicólogo nos NASF: Desafios e perspectivas na atenção básica. Temas em Psicologia, 25(1), 291-304. doi: 10.9788/TP2017.1-17Pt

Oliveira, I. F., Dantas, C. M. B., Solon, A. F. A. C. \& Amorim, K., M. O. (2011). A prática psicológica na proteção social básica do SUAS [Special issue]. Psicologia \& Sociedade, 23, 140-149. doi: 10.1590/S0102-71822011000400017

Oliveira, I. F., Oliveira, N. L. A., Nascimento, M. N. C., Araújo, R. L., Coelho-Lima, F., \& Amorim, K. M. O. (2014). Atuação dos psicólogos nos CRAS do interior do RN [Special issue]. Psicologia \& Sociedade, 26(2), 103-112. doi: $10.1590 / \mathrm{S} 0102-71822014000600011$

Romagnoli, R. C., \& Moreira, M. I. C. (2014). SUAS - Sistema Único de Assistência Social: Articulações entre psicologia e o serviço social no campo da proteção social, seus desafios e perspectivas. Curitiba, PR: CRV Editora.

Santos, K. R., Monteiro, L. G., Torres, M. L. C., Sousa, L. G., \& Coelho, A. R. (2014). Perfil dos psicólogos inscritos na subsede leste do CRP04. Psicologia: Ciência e Profissão, 34(4), 864 878. doi: 10.1590/1982-370000162013
Senra, C. M. G., \& Guzzo, R. S. L. (2012). Assistência social e psicologia: Sobre as tensões e conflitos do psicólogo no cotidiano do serviço público. Revista Psicologia \& Sociedade, 24(2), 293-299. Retrieved from http://www.scielo.br/ pdf/psoc/v24n2/05

Seixas, P. S. (2009). Inserção e atuação do psicólogo no campo das políticas sociais no Rio Grande do Norte (Master's thesis, Universidade Federal do Rio Grande do Norte, Natal, RN, Brazil). Retrieved from https://repositorio.ufrn.br/jspui/bitstream/123456789/17438/1/PabloSS.pdf

Seixas, P. S., Costa, A. L. F., Oliveira, A. M. de, Costa, J. P. da, \& Yamamoto, O. H. (2016). As políticas sociais nas disciplinas dos cursos de graduação em Psicologia no Brasil. Psicologia em Pesquisa, 10(1), 9-16. doi: 10.24879/201600100010042

Yamamoto, O. H. (2007). Políticas sociais, terceiro setor e compromisso social: Perspectivas e limites do trabalho do psicólogo. Psicologia \& Sociedade, 19(1), 30-37. doi: 10.1590/S010271822007000100005

Received: $15 / 02 / 2018$

$1^{\text {st }}$ revision: 09/05/2018 Accepted: 11/05/2018

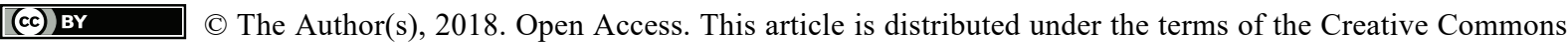
Attribution 4.0 International License (http://creativecommons.org/licenses/by/4.0/), which permits unrestricted use, distribution, and reproduction in any medium, provided you give appropriate credit to the original author(s) and the source, provide a link to the Creative Commons license, and indicate if changes were made. 